
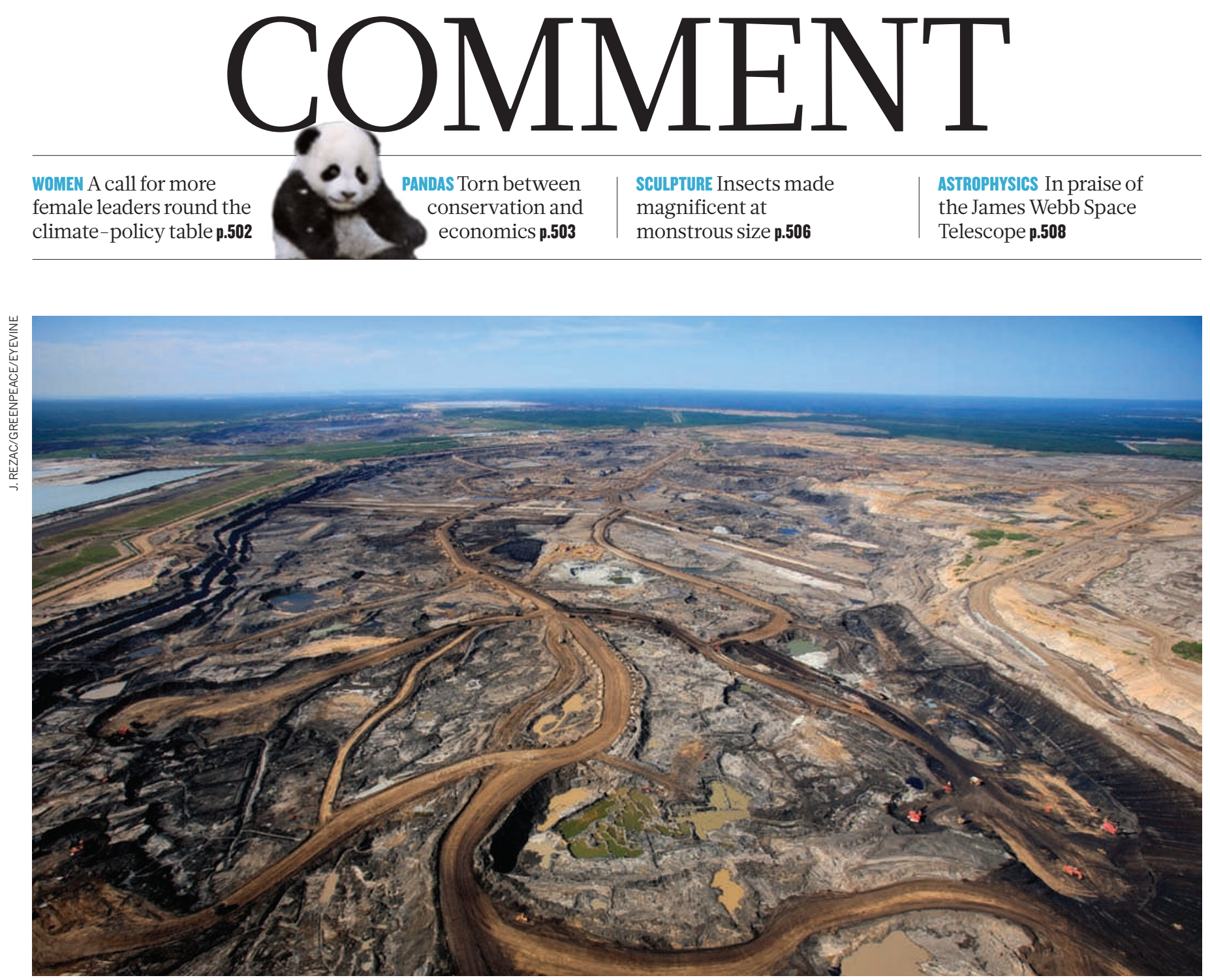

\title{
Tar sands need solid science
}

As Canada exploits its oil sands ever faster, David Schindler calls for industryindependent environmental monitoring to back up better water-quality regulation.

$\mathrm{W}$ hen Canadian-born movie director James Cameron visited his home country's tar-sands mining operation this September, he concluded: "The oil sands can be either a blessing or a curse to Alberta, depending on how they are developed." He called for better monitoring, independent research, more consideration of the needs of aboriginal groups and a slowdown of development until better technologies are developed. It seems the creator of Avatar and Titanic - movies that showcase disasters following hubris - is better able than local politicians and industrialists to see that megadevelopments often don't have rosy outcomes.
The debate about oil-sands extraction has become polarized, with players cast as either totally against, or for developing the sands rapidly without regard for environmental consequences. Both positions are based on very little evidence. A more moderate approach, with the pace of development based on solid environmental science, would be better in the long run.

The current environmental monitoring programmes for Alberta's waterways are in my view sporadic and poorly designed. Water quality - in which I have expertise and have done research in the tar-sands area - is not the only, or even the main, problem. There are serious concerns about issues including possible disastrous ruptures of tailings ponds that could spread toxic chemicals as far as the Beaufort Sea, the low rate at which land is being reclaimed after the end of mining, and greenhouse-gas emissions. Regulation is a problem in these areas too, but basic improvements in monitoring science would not help to sort these things out easily. By contrast, better information could make a big difference to water quality.

\section{MINING BOOM}

Industrial development of Alberta's oil sands began in 1967. The cost of producing usable oil from the bituminous sands was high, and companies struggled for 
the next 30 years. As the price of conventional oil edged upwards at the turn of the millennium, development in the oil sands increased at a frantic pace. Production rocketed from 760,000 barrels of oil a day in 2005 to 1.3 million barrels a day in 2006, and is projected to reach 3.3 million barrels or more a day by 2020 . The proven reserve is listed as the planet's second largest after Saudi Arabia, with around 170 billion barrels recoverable at 2006 prices.

The extraction of oil from the sands is energy intensive: the energy cost per barrel is higher than for conventional crude oil, although it is difficult to quantify the lifecycle emission differences. Emissions of carbon dioxide from the Canadian oil sands are expected to reach 108 megatonnes by 2020 - a fifth of Canada's current national emissions. The extraction also requires a huge amount of water $-2-5$ barrels of water per barrel of oil. Much of the used water ends up in toxic tailings ponds, which can kill birds that land in them and are suspected of seeping chemicals into groundwater.

By 2008, the industrial footprint of the oil-sands operation was $650 \mathrm{~km}^{2}$ - about one-hundredth the size of Alberta (or Texas). The area of mine pits and tailings ponds is about four times larger than it was in 1992. Environmental groups and the handful of aboriginal communities living in towns near the oil sands (see map) have repeatedly warned that the rapid development has come at too high a cost to the environment.

The Canadian Association of Petroleum Producers, based in Calgary, Alberta, oilsands companies and the Alberta provincial government have responded to criticism with their own publicity campaign. Websites, large newspaper ads, TV commercials and even electronic billboards in New York's Times Square and Piccadilly Circus in London portray oil-sands development as environmentally responsible. One ad aimed at US audiences reads "A good neighbor lends you a cup of sugar. A great neighbor

provides you with 1.4 million barrels of oil per day. And does it responsibly." Other ads tout the province's commitment to carbon capture and storage - in 2008, it committed to invest US\$2 billion in the technology - and to protecting land and water. But, so far, carbon capture and storage is only at the developmental stage, and there seems little prospect of it reducing emissions substantially. Nor do I think that water is being sufficiently protected.

\section{OIL IN WATER}

Bitumen contains a potent brew of toxic organic and inorganic chemicals. Lab studies show that fish eggs laid on sediments contaminated with bitumen often die, and survivors have high rates of malformations including spinal deformities, lesions, haematomas and eye defects ${ }^{1,2}$. Similar malformations are observed in adult fish caught downstream of the oil sands by abo-

riginal people who rely on fish as a major source of protein. Researchers have seen slightly increased incidences of

"The fox has been left in charge of the henhouse." cancer in people downstream of the tar sands, which could be due to chance or industrial pollution ${ }^{3}$. More work is needed to investigate this question.

So far, no government agency seems to have taken full responsibility for ensuring adequate monitoring of the Athabasca River and its tributaries, which run through the area. The hazy Canadian constitution gives jurisdiction over fish and water that flows across provincial boundaries to the federal government and jurisdiction over land (including watersheds) to the provinces. Responsibilities and monitoring tasks are split between federal bodies including Environment Canada and Fisheries and Oceans Canada, and the provincial body Alberta Environment. Much of the water monitoring has ended up with the Regional Aquatics Monitoring Program (RAMP) - a body with some serious shortcomings.

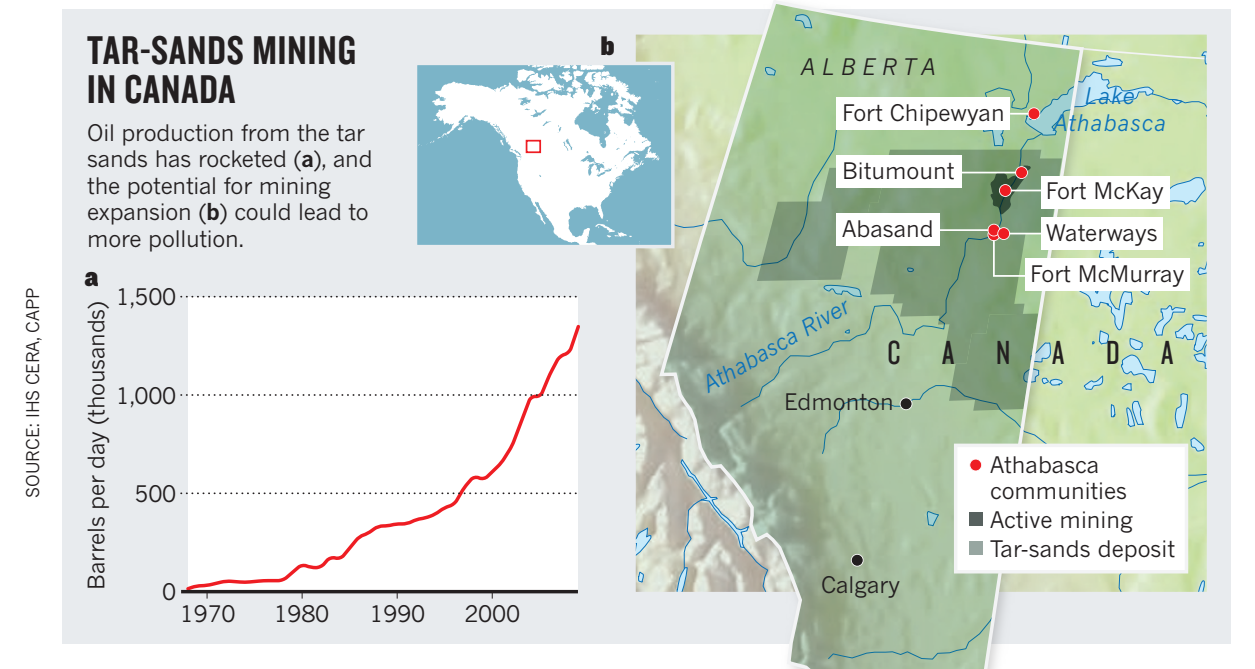

RAMP is an industry-funded group designed to involve stakeholders from a wide range of groups including local and aboriginal communities, environmental non-governmental organizations (NGOs), government agencies at all levels, oil-sands developers and other industries. However, some aboriginal communities and environmental NGOs have left RAMP, expressing concerns about their opportunity to participate meaningfully or about the group's links with industry. According to a RAMP spokesperson, the group currently counts only 1 aboriginal community and no NGOs among its members, along with 8 government bodies, 12 energy companies and a gravel-mining company. The fox has been left in charge of the henhouse.

In 2004, a review of RAMP by three federal senior scientists highlighted "a serious problem related to scientific leadership", inconsistent sampling and methodology, and lack of accessibility to data ${ }^{4}$. It concluded that RAMP's data collection made it impossible to determine, for example, the extent to which mining has increased the concentrations of contaminants in the river over natural background levels. RAMP responded to this review by making some changes, including promising to open up its database to public view online - which hasn't happened yet. A new independent review of RAMP is due in December; I expect it will continue to find problems with the organization and its data.

Thanks in part to the past inaccessibility of RAMP data, there have been few independent analyses of its results. Kevin Timoney, a consultant for the Mikisew Cree First Nation band of aboriginal people, was able to obtain access before that group resigned from RAMP in November 2009. He and a colleague concluded that RAMP's data show increases in the concentrations of mercury in fish, and of polycyclic aromatic hydrocarbons in river water and sediments ${ }^{5}$. RAMP did not comment, but an Alberta Environment representative publicly attacked the study, accusing the authors of, among other things, lying and removing data from the study. Faced with a threat of legal action, he sent the authors a letter of retraction and apology this summer.

The Canadian House of Commons Standing Committee on Environment and Sustainable Development held 18 months of hearings in 2009 and 2010 on water issues in the oil sands. More than 60 witnesses testified. But the committee never issued a public report. According to news stories in July 2010, the committee destroyed the draft copies after failing to reach a consensus. The minority Liberal and New Democratic parties issued their own reports on the hearings ${ }^{6,7}$, condemning the state of the science and the monitoring programme, and identifying many topics on which federal responsibilities 

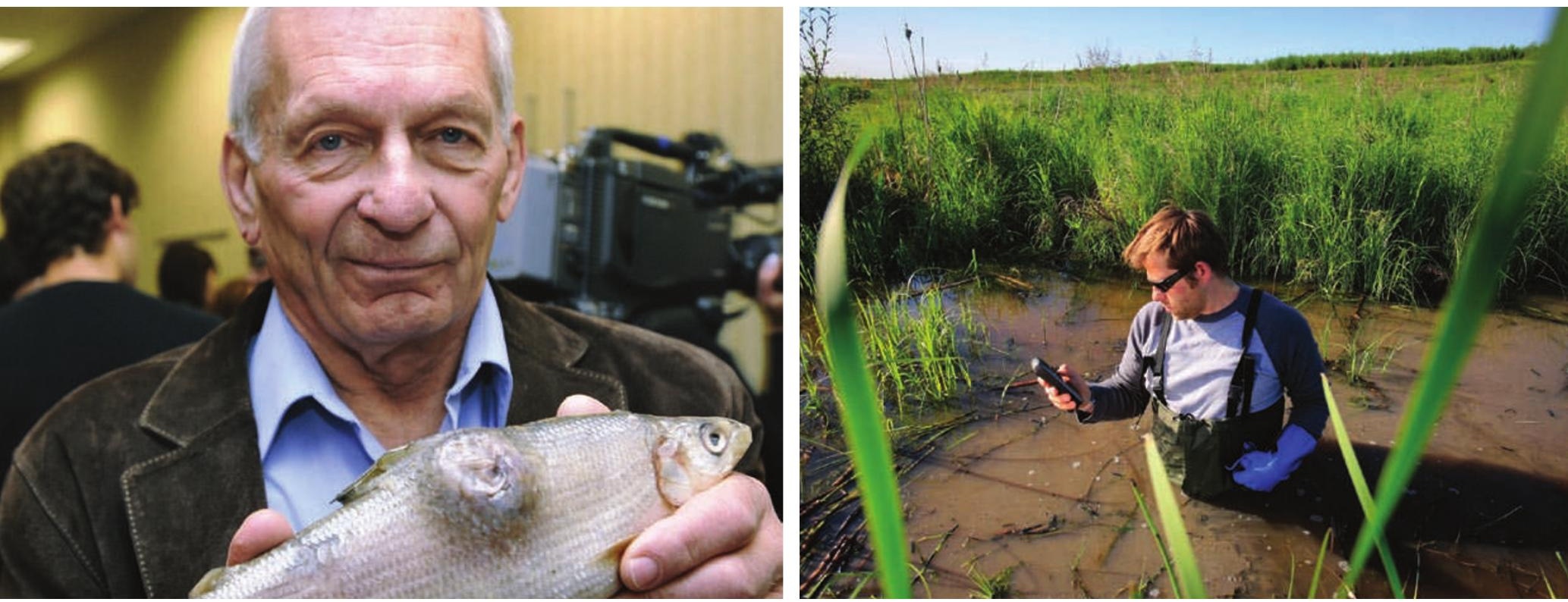

Author David Schindler (left) holding a deformed whitefish from the Athabasca River. Scientists and activists (right) are trying to assess pollution in the area.

were being ignored, including protection of the Mackenzie River watershed (of which the Athabasca River is a part), aboriginal peoples, lands and species at risk. The oil industry and Alberta politicians largely dismissed these concerns.

\section{EVIDENCE BASE}

To redress the scarcity of peer-reviewed science, in 2007 I formed a small group of experts to test a frequent claim of the oil-sands industry and Alberta government that toxins in the Athabasca River and its tributaries are from natural seepage from bitumen deposits. This seemed unlikely, given the probable erosion of areas cleared of soil and vegetation for industrial use, seepage from $130 \mathrm{~km}^{2}$ of tailings ponds, and airborne emissions from coke-fired upgraders that convert raw bitumen to synthetic crude oil. We mounted two field expeditions in 2008 - one during winter when the river was ice-covered and four months of snow had accumulated, and another during midsummer. As expected, we found a wide variety of toxic contaminants deposited in the snowpack, some detectable as far as $50 \mathrm{~km}$ from the main pollutant sources. In the river system, we found that industry added substantially to the natural contaminant loading ${ }^{8,9}$. Alberta Environment continues to counter that environmental contaminants are largely natural in origin - even though, as far as I can tell, they have published no studies of atmospheric deposition of trace contaminants.

Two panels of experts, one federal and one provincial, have been appointed to resolve the disagreement between our conclusions and those of RAMP and provincial monitoring programmes. The federal panel is expected to report to the minister of the environment by mid-December 2010, the provincial panel two months later. The panels contain recognized experts in the fields of water pollution, watershed monitoring and petroleum science; some are members of the Royal Society of Canada.

Ideally, Environment Canada should assume responsibility for monitoring the Athabasca River and its tributaries. They are the only agency with the necessary expertise in both contaminant chemistry and watershed monitoring. The sampling programme must be strategically designed to monitor airborne and waterborne pathways of contaminants, and to separate industrial from natural sources. Seasonal changes, such as the influx of pollutants from contaminated snow during spring snow melt, must be accounted for. Special attention must be paid to assessing the cumulative effects of so many megaprojects in one watershed ${ }^{10}$.

Overall, the effort needed is several times that currently invested by all groups in monitoring this important river. In addition, to restore public trust, a panel of independent scientists and community leaders should be formed to provide oversight of this monitoring programme. Results should be published in peer-reviewed scientific papers, and reported to the public at large. A good model is the US Geological Survey's National WaterQuality Assessment Program.

Meanwhile, the rush for expansion in the oil sands is resuming, after a months-long lull caused by the global recession. French energy giant Total is proposing another huge surface mine, and a decision by the provincial Energy Resources Conservation Board (ERCB) is expected by the end of 2010. The hearings for such applications follow a script as predictable as an opera: 'experts' sing their arias in praise of, or in opposition to, development of the oil sands, generating hundreds of pages of testimony. The cast may vary, but the audience can guess the outcome: although the ERCB has added conditions and amendments to oilsands proposals, it has never yet rejected a project.

In the face of such rampant expansion, it is ever-more vital that we have good, visible data against which the public can hold regulators to account. With better science in place to monitor water quality and protect the environment, moderation in oil-sands development should follow.

David Schindler is an ecologist at the University of Alberta, Edmonton, Alberta T6G 2E9, Canada.

e-mail:d.schindler@ualberta.ca

1. Colavecchia, M. V. et al. J. Toxicol. Environ. Health Part A 69, 967-994 (2006).

2. Colavecchia, M. V. et al. J. Toxicol. Environ. Health Part A 70, 1542-1555 (2007)

3. Chen, Y. Cancer Incidence in Fort Chipewyan, Alberta 1995-2000 (Alberta Cancer Board, Edmonton, 2009)

4. Ayles, G. B. et al. Oil Sands Regional Aquatic Monitoring Program (RAMP) Scientific Peer Review of the Five Year Report (1997-2001) (Fisheries and Oceans Canada, Winnipeg, 2004); available at go.nature.com/tdsuag

5. Timoney, K. P. \& Lee, P. Open Conserv. Biol. J. 3, 65-81 (2009)

6. New Democrat Party of Canada. Missing in Action: The Federal Government and Protection of Water in the Oil Sands (2010); available at go.nature.com/pzuypx

7. Liberal Party of Canada. The Hidden Dimension: Water and the Oil Sands (2010); available at go.nature.com/63vitb

8. Kelly, E. N. et al. Proc. Natl Acad. Sci. USA 106, 22346-22351 (2009).

9. Kelly, E. N. et al. Proc. Natl Acad. Sci. USA 107, 16178-16183 (2010)

10.Squires, A. J., Westbrook, C. J. \& Dubé, M. G. Integr. Environ. Assess. Monit. 6, 119-134 (2009).

Further reading accompanies this article online at go.nature.com/qz5tki 